\title{
Effect of Jiaji electroacupuncture in transected rat spinal cord
}

\author{
TENG XiuYing, WANG DeSheng ${ }^{*}$, ZHANG XiaoMei, LAI ZengJiao, JIANG HaiXia, \\ WU JianLi, QI Huan, YU Qian, YAO Shun, SONG WenBo, YANG JingJie \& LI AiMu
}

The First Affiliated Hospital of Harbin Medical University, Harbin 150040, China

Received April 30, 2011; accepted June 22, 2011; published online December 8, 2011

\begin{abstract}
We evaluated the effect of Jiaji electroacupuncture on cell proliferation and the expression of markers of endogenous neural stem cell activation after complete spinal cord transection. Female Wistar rats were assigned to 4 groups ( $n=24$ each): a sham-operated group, a control group, a Jiaji electroacupuncture group, and a Jiaji electroacupuncture preconditioning group. Motor function was significantly improved in the acupuncture groups compared to the control group at 7 and $14 \mathrm{~d}$. Numbers of bromodeoxyuridine (BrdU)-, nestin-, and glial fibrillary acidic protein (GFAP)-positive cells were significantly greater in the acupuncture groups than in the controls at each time point. Expression of nestin and GFAP mRNA was significantly higher in the acupuncture groups than in the controls at each time point. Thus, Jiaji electroacupuncture and preconditioning may promote the proliferation of endogenous neural stem cells after spinal cord transection.
\end{abstract}

Jiaji electroacupuncture, spinal transection, rat, endogenous neural stem cells

Citation: Teng X Y, Wang D S, Zhang X M, et al. Effect of Jiaji electroacupuncture in transected rat spinal cord. Chin Sci Bull, 2012, 57: 762-768, doi: $10.1007 / \mathrm{s} 11434-011-4839-7$

Spinal cord injury can cause disability or death. It has long been believed that the adult mammalian central nervous system is incapable of regeneration or repair and that damage results in permanent disability. However, many recent studies have identified and characterized neural stem cells in adult mammals, including human, that show some central nervous system renewal ability [1]. Neural stem cells are normally dormant; however, they can be induced by stimuli such as damage or ischemia to proliferate and migrate to sites of damage to replace necrotic neurons, repair lesions, and restore neural function. This brings new hope for successful treatment of spinal cord injuries. At present, there are 2 treatment approaches for spinal cord injury using neural stem cells: transplantation of exogenous neural stem cells and activation of endogenous neural stem cells. Although much progress has been made with respect to the former, technical issues such as immunologic rejection and ethical issues regarding the use of stem cells remain [2]. Therefore, activation of endogenous neural stem cells may

*Corresponding author (email: wangdesheng5678@126.com) be more appropriate for clinical application.

In 1920, it was first reported that electric fields play a role in nerve growth and reduction of injured nerve degeneration [3]. Electrical stimulation can promote the proliferation and differentiation of endogenous neural stem cells and has been reported to enhance the reparative ability of nervous tissue $[4,5]$. Acusector and electric field treatments have been used for spinal cord injuries in both experimental animals and clinical practice [6-9]. Jiaji, also termed "Xieji" or "Xiaji," refers to acupuncture points (acupoints) located on either side of the vertebral column. References to these points were found in the early Chinese medical literature (Huangdi Neijing). Cheng [10] confirmed the locations of these acupoints (termed Hua Tuo Jiaji acupoints) bilaterally, $15 \mathrm{~mm}$ below the spinal processes from $\mathrm{T} 1$ to L5 and totaling 17 pairs. Jiaji acupuncture entails the use of 4 needles: 2 above the level of damage and 2 below. Jiaji electroacupuncture involves the application of an electric current to the needles [11]. A pulsed electric field reportedly promotes vascularization and regeneration of nervous tissue [12], and electroacupuncture has been shown to promote functional 
recovery after spinal cord injury [13]. This method improves blood circulation and relieves edema after spinal cord injury [14], and it can protect and promote axonal regeneration $[15,16]$. The electromagnetic field effects of electroacupuncture promote neuronal polarization, enzymatic activity [17], and gene expression [18,19].

We were interested in determining whether Jiaji electroacupuncture can activate neural stem cells in the context of the injured spinal cord. We were interested specifically in the Jiaji point because of its position relative to the spinal cord. Therefore, the aim of the present study was to investigate the effect of Jiaji electroacupuncture on markers of endogenous neural stem cell activation, including bromodeoxyuridine (BrdU), nestin, and glial fibrillary acidic protein (GFAP), after complete spinal cord transection in rats.

\section{Materials and methods}

\subsection{Animals and study design}

The animal treatment protocol was approved by the Review Board of Heilongjiang University of Chinese Medicine (Harbin, China). Ninety-six adult (11-12 weeks of age; 200-220 g) female Wistar rats (Animal Experiment Center, Heilongjiang University of Traditional Chinese Medicine) were randomly assigned to 1 of 4 groups: a sham-operated group in which the spinal cord was exposed but not transected; a control group in which the spinal cord was completely transected at T10 but not treated; a Jiaji electroacupuncture group in which rats were treated for 3,7 , or $14 \mathrm{~d}$ after transection; and a Jiaji electroacupuncture preconditioning group in which rats were treated for 1 week before transection in addition to treatment after transection. Rats in each group were killed at 3, 7, and $14 \mathrm{~d}$ after transection (n $=8$ per time point in each group). Spinal cord tissues from 4 rats at each time point were assessed by immunohistochemistry, and 4 were assessed by real-time quantitative polymerase chain reaction (PCR). We also assessed neural conduction from L2 to T8 in each group.

\subsection{Spinal cord transection}

For spinal cord transection, rats were anesthetized with $10 \%$ chloral hydrate $(400 \mathrm{mg} / \mathrm{kg}$, intraperitoneal injection) and fixed in a prone position. The back skin was disinfected, the skin and subcutaneous tissue were cut, and the spine was exposed at the level of T8 to T10. The neural scute was cut with surgical forceps, and the spinal cord was exposed at the level of T9 to T11. The spinal cord was completely transected at the level of T10 [20] with microscissors [21,22] and then covered with a gelatin sponge. The wound was stitched, and $1.6 \times 10^{5} \mathrm{U}$ penicillin was infused intraperitoneally once a day for $5 \mathrm{~d}$. The bladder was stimulated by pressure until recovery of micturition, and $0.1 \mathrm{mg} / \mathrm{kg}$ neostigmine was administered to promote gastrointestinal per- istalsis. After recovery, food and water were supplied ad libitum.

\subsection{Jiaji electroacupuncture and assessment of motor function}

The Jiaji method was applied according to Lin [23] and Zhang et al. [24]. The acupuncture position was 3 to $4 \mathrm{~mm}$ from the clearance of the 2 adjacent processus spinosus vertebrae. The 2 upper needles were placed beside the clearance of the 2 processus spinosus vertebrae above the level of transection. Two additional needles were placed beside the clearance of the 2 processus spinosus vertebrae below the level of transection. The 25-mm Hua Tuo needles were placed vertically at a depth of 4 to $5 \mathrm{~mm}$, with the tip of each needle touching the lamina. An electric acupuncture stimulator (KWD-808 II; Great Wall, Jiangsu, China) was used to apply a pulse current to the needle handle, with the positive pole at the upper needle handle and the negative pole at the lower needle handle. A condensation wave was applied at a frequency of $100 \mathrm{~Hz}$, and the output current was set to activate mild twitching of the back muscles. Rats in the Jiaji electroacupuncture group were treated for $15 \mathrm{~min}$ at $30 \mathrm{~min}, 4 \mathrm{~h}$, and $8 \mathrm{~h}$ after transection and then once a day for 3,7 , or $14 \mathrm{~d}$. Rats in the Jiaji electroacupuncture preconditioning group were treated for $15 \mathrm{~min}$ once a day for 1 week before transection. After transection, the treatment was the same as that for the electroacupuncture group. Motor function was assessed after spinal cord transection according to the Basso, Beattie, and Bresnahan (BBB) openfield locomotor scale [25]. Two experienced observers performed scoring at 3, 7, and $14 \mathrm{~d}$ after transection, and the scores were averaged.

\subsection{Immunohistochemistry}

Rats were administered an intraperitoneal injection of $1 \%$ of BrdU (150 mg/kg; Sigma-Aldrich, St. Louis, MO, USA) in physiologic saline $3 \mathrm{~d}$ before they were killed by injection with $10 \%$ chloral hydrate $(400 \mathrm{mg} / \mathrm{kg})$ and perfused with $4 \%$ paraformaldehyde. The spinal cord surrounding the level of transection was removed and placed in $4 \%$ paraformaldehyde for $24 \mathrm{~h}$ and then embedded in paraffin. For immunohistochemistry, $2-\mu \mathrm{m}$-thick tissue sections were dewaxed, and antigen retrieval was performed by steam treatment. Sections were incubated in $3 \%$ hydrogen peroxide for $10 \mathrm{~min}$ and then incubated overnight with monoclonal BrdU antibody (1:200; NeoMarkers, Fremont, CA, USA), polyclonal nestin antibody (1:400; Abcam, Cambridge, UK), or GFAP antibody (1:400; Wuhan Boster Biological Technology, Wuhan, China) at $4^{\circ} \mathrm{C}$ and then incubated with reagents of a PV6001/6002 2-step immunohistochemistry kit (Zhongshan Golden Bridge Biotechnology, Beijing, China) for $30 \mathrm{~min}$ at room temperature. 3,3'-Diaminobenzidine developer was then added dropwise 
while observing the development of a yellow-brown color under a microscope (Nikon, Tokyo, Japan) for 10 to $30 \mathrm{~min}$. Sections were counterstained with hematoxylin. Positive cells were counted for 5 randomly selected microscopic fields $(400 \times)$ per section.

\subsection{Real-time PCR}

For RNA isolation, rats were killed by decapitation, and the spinal cord surrounding the transection was rapidly removed and stored at $-80^{\circ} \mathrm{C}$ until use. Total RNA was isolated with RNAiso Plus reagent (Takara Bio, Shiga, Japan). Reverse transcription (RT) was performed in a volume of $10 \mu \mathrm{L}$ containing $5 \times$ PrimeScript Buffer $(2 \mu \mathrm{L})$, PrimeScript RT Enzyme Mix $(0.5 \mu \mathrm{L})$, Oligo dT Primer $(0.5 \mu \mathrm{L})$, random 6 mers $(0.5 \mu \mathrm{L})$, total RNA $(4 \mu \mathrm{L})$, and RNase-free $\mathrm{H}_{2} \mathrm{O}(2.5 \mu \mathrm{L})$ (all from Takara Bio). The reaction was performed for $15 \mathrm{~min}$ at $37^{\circ} \mathrm{C}$ followed by $5 \mathrm{~s}$ at $85^{\circ} \mathrm{C}$. Amplification products were stored at $-80^{\circ} \mathrm{C}$ until use in PCR. Primer sequences for real-time fluorescence quantitative PCR were as follows (Takara Bio): glyceraldehyde 3-phosphate dehydrogenase (GAPDH) (143 bp), 5'-GGCACAGTCAAGGCTGAGAATG-3' and 5'-ATGGTGGTGAAGACGCCAGTA-3'; GFAP (163 bp), 5'-AGTGGCCACCAGTAACATGCAA-3' and 5'-GGACTCAAGGTCGCAGGTCAA-3'; and nestin (101 bp), 5'-CAGCAACTGGCACACCTCAAG-3' and 5'-CCTCGTCCAGGTGTCTGCAA-3'. Relative GFAP and nestin mRNA expression was calculated according to the threshold cycle method with the use of GAPDH as an internal control [26]. PCR was performed in a total volume of $25 \mu \mathrm{L}$, including RT-PCR mix and $0.5 \mu \mathrm{L}$ of each primer. The PCR condition was as follows: $30 \mathrm{~s}$ at $95^{\circ} \mathrm{C}$ followed by 40 cycles of $5 \mathrm{~s}$ at $95^{\circ} \mathrm{C}$ for denaturation and $30 \mathrm{~s}$ at $60^{\circ} \mathrm{C}$ for annealing and elongation. Dissociation curve analysis was performed after PCR. Agarose gel electrophoresis was performed to verify amplification. For assessment of amplification efficiency, a standard curve was created for each PCR target with diluted cDNA $(20,10,5$, 2.5 , and $1.25 \mathrm{ng}$ ) plotted versus corresponding $\mathrm{Ct}$; amplification efficiency was calculated according to $E=10^{-\mathrm{S}}-1$.

\subsection{Assessment of neural conduction}

To assess neural conduction, rats were anesthetized with an abdominal injection of $10 \%$ chloral hydrate $(400 \mathrm{mg} / \mathrm{kg})$ and placed in the prone position. Incisions were made to expose the skull, L2 and T8 of the spinal cord, and the sciatic nerve of the left hind limb. A Danmark Dantec Keypoint electromyography/evoked potential (EP) system (Skovlunde, Denmark) was used to assess EPs of somesthetic sensation and conduction speed. Electrodes were 15-mm Hua Tuo filiform needles. The recording electrode for the spinal cord was fixed to the intraspinous ligament between L1 and L2. The recording electrode for the cortex was fixed to the intraspinous ligament between $\mathrm{T} 7$ and $\mathrm{T} 8$.
Reference electrodes were fixed 1 to $2 \mathrm{~cm}$ from recording electrodes. The stimulation electrode was fixed to the caput fibulae. An appropriate level of stimulation was determined to be that which generated small motions of the ankle joint. Stimulation was set at 0.4 to $0.8 \mathrm{~mA}$, the stimulation period was $0.2 \mathrm{~ms}$, frequency was $30 \mathrm{~Hz}$, superposition time was 200 times, scanning speed was $3 \mathrm{~ms} / \mathrm{D}$, and sensitivity was $10 \mu \mathrm{V} / \mathrm{D}$. The stimulation point on the body surface was fixed to the other caput fibulae. We then assessed the conduction time from the recording stimulation point to the spinous process of L1 to L2 and T7 to T8 and the spinal cord conduction velocity (SCCV) from L2 to T8.

\subsection{Statistical analysis}

Data are presented as mean \pm standard deviation for normally distributed continuous variables and were tested by 1-way analysis of variance. Tukey's test or Dunnett's test was then utilized for post hoc analysis of continuous variables with or without equal variance between groups. The BBB score is presented as the median (interquartile range) because of non-normal distribution. The difference in BBB score among groups was verified by the Kruskal-Wallis test, and the Mann-Whitney $U$ test was applied for post hoc analysis of BBB scores. A 2-sided $P<0.05$ was considered statistically significant, and the significance level was adjusted to 0.005 (=0.05/number of post hoc tests) when the Mann-Whitney $U$ test was implemented. Statistical analyses were performed with SPSS statistical software (v. 15.0; SPSS Inc., Chicago, IL, USA).

\section{Results}

\subsection{Motor function}

BBB scores for the 4 groups of rats are listed in Table 1. At day 3 after transection, a significant $(P<0.001)$ difference between the sham group and the other 3 groups was observed, as expected. However, motor function scores were significantly $(P<0.001)$ higher in the acupuncture treatment groups (electroacupuncture and preconditioning) than in the control group (transection but no acupuncture treatment) at days 7 and 14 after transection.

\subsection{Immunohistochemistry and PCR results}

Immunohistochemical staining for BrdU, nestin, and GFAP is shown in Figures 1-3, and quantification of immunopositivity for these markers among the 4 groups is summarized in Table 2. The numbers of BrdU-, nestin-, and GFAPimmunopositive cells were significantly $(P<0.001)$ greater in the acupuncture treatment groups than in the control group at each time point. In addition, the effect was greater in the preconditioning Jiaji electroacupuncture group than in the group that received electroacupuncture after transection 
Table 1 Motor function of different groups 3, 7 and $14 \mathrm{~d}$ after spinal cord transection as assessed by Basso, Beattie and Bresnahan scores ${ }^{\text {a) }}$

\begin{tabular}{|c|c|c|c|c|c|}
\hline & $\begin{array}{c}\text { Sham } \\
(n=8 / \text { time point })\end{array}$ & $\begin{array}{c}\text { Control } \\
(n=8 / \text { time point })\end{array}$ & $\begin{array}{l}\text { Electroacupuncture } \\
(n=8 / \text { time point })\end{array}$ & $\begin{array}{l}\text { Preconditioning } \\
(n=8 / \text { time point })\end{array}$ & $P$ value \\
\hline Day 3 & $21.0(21.0,21.0)^{\mathrm{a}}$ & $0(0,0)^{\mathrm{b}}$ & $0(0,0)^{\mathrm{b}}$ & $0(0,0)^{\mathrm{b}}$ & $<0.001^{*}$ \\
\hline Day 7 & $21.0(21.0,21.0)^{\mathrm{a}}$ & $1.0(0,1.0)^{\mathrm{b}}$ & $2.0(1.5,2.0)^{\mathrm{c}}$ & $4.0(3.5,4.5)^{\mathrm{d}}$ & $<0.001^{*}$ \\
\hline Day 14 & $21.0(21.0,21.0)^{\mathrm{a}}$ & $4.0(3.0,4.5)^{\mathrm{b}}$ & $6.0(5.5,6.0)^{\mathrm{c}}$ & $8.5(7.5,9.5)^{\mathrm{d}}$ & $<0.001^{*}$ \\
\hline
\end{tabular}

a) Data are presented as median (interquartile range) and were tested by Kruskal-Wallis test; Mann-Whitney $U$ test with adjusted $\alpha^{\prime}(=0.05 / 10=0.005)$ was implemented for post-hoc analysis. *, Significantly different among the 4 groups. Different letters $(a, b, c, d)$ indicate significant $(P<0.005)$ differences between groups.
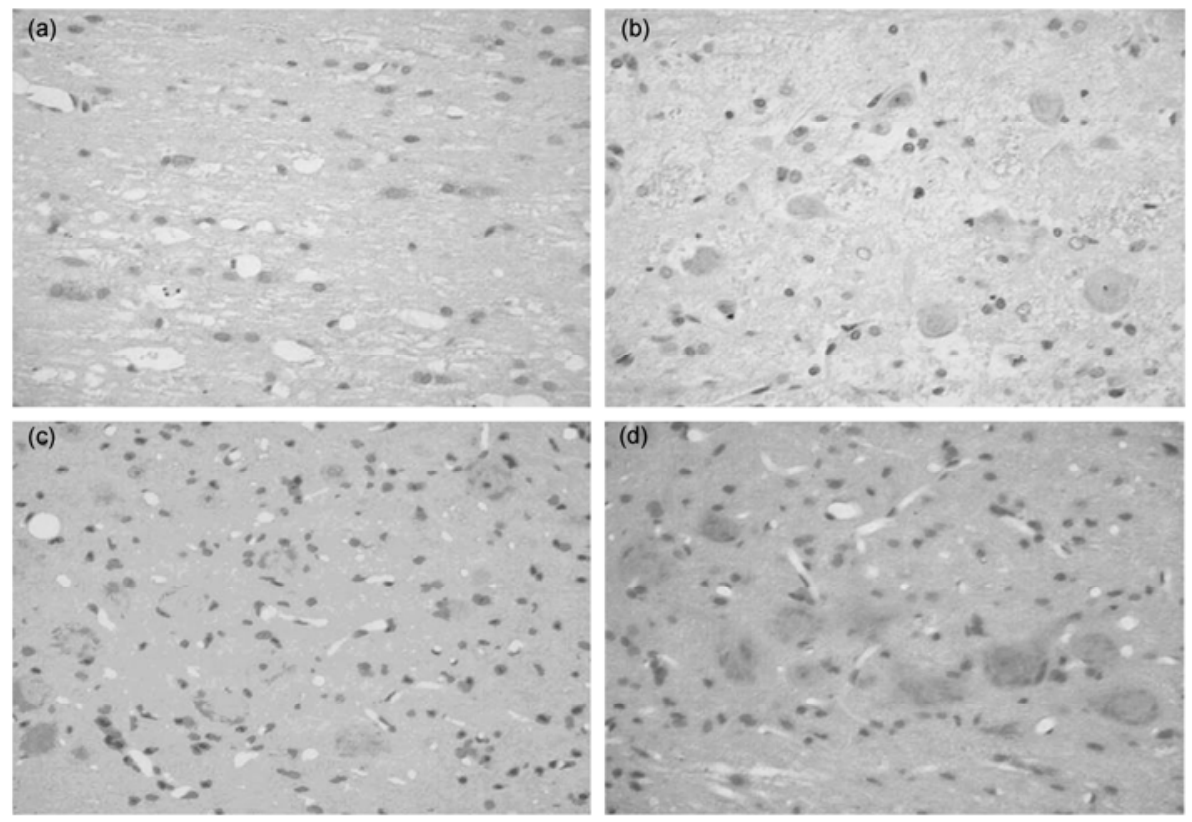

Figure 1 Representative images of nestin immunostaining in spinal cord tissue from sham-treated rats (a), control rats (b), rats receiving electroacupuncture preconditioning treatment (c), and rats receiving electroacupuncture treatment for 1 week after spinal cord transection (d).

alone. mRNA expression for these neural stem cell markers is summarized in Table 3. The expression of nestin and GFAP mRNA was significantly $(P<0.001)$ greater in the treatment groups than in the control group at each time point.

\subsection{Neural conduction}

Table 4 shows the numbers of rats in each group with detectable conduction from L2 to T8 at different times after sectioning. Conduction speed in the sham group was faster than that in the electroacupuncture or preconditioning group at each time point after sectioning. On the 14th day after sectioning, conduction speed in the electroacupuncture group $(12.13 \mathrm{~m} / \mathrm{s} ; n=4)$ and the preconditioning group $(25.04 \mathrm{~m} / \mathrm{s} ; n=7)$ was faster than that in the control group $(3.01 \mathrm{~m} / \mathrm{s} ; n=3)$. In addition, conduction speed in the electroacupuncture and preconditioning groups on the 14th day were faster than those at the 7 th day $(3.08 \mathrm{~m} / \mathrm{s}$ in the electroacupuncture group $(n=3)$ vs. $12.13 \mathrm{~m} / \mathrm{s}$ in the preconditioning group $(n=4))$.

\section{Discussion}

The aim of the present study was to assess the effect of Jiaji electroacupuncture on cell proliferation and the expression of nestin and GFAP, as markers of neural stem cells, in transected rat spinal cord. Results showed that Jiaji electroacupuncture, applied either after transection or both before and after transection, increased cell proliferation in the spinal cord as assessed by BrdU staining and cell quantification and increased the number of cells positive for nestin and GFAP immunostaining compared with the control group.

We assessed 3 markers of neural stem cells in this study. BrdU intercalates into DNA and is used as a marker of cell division and proliferation. Nestin, also termed nidogen, is an intermediate filament protein expressed in neuroepithelial precursor cells and adult pluripotent stem cells [27]. GFAP is commonly used as a marker of glial response to injury, and astrocytes can differentiate along multiple lines and exert various effects in response to spinal cord injury $[28,29]$. In fact, Lang et al. reported that astrocytes can revert 

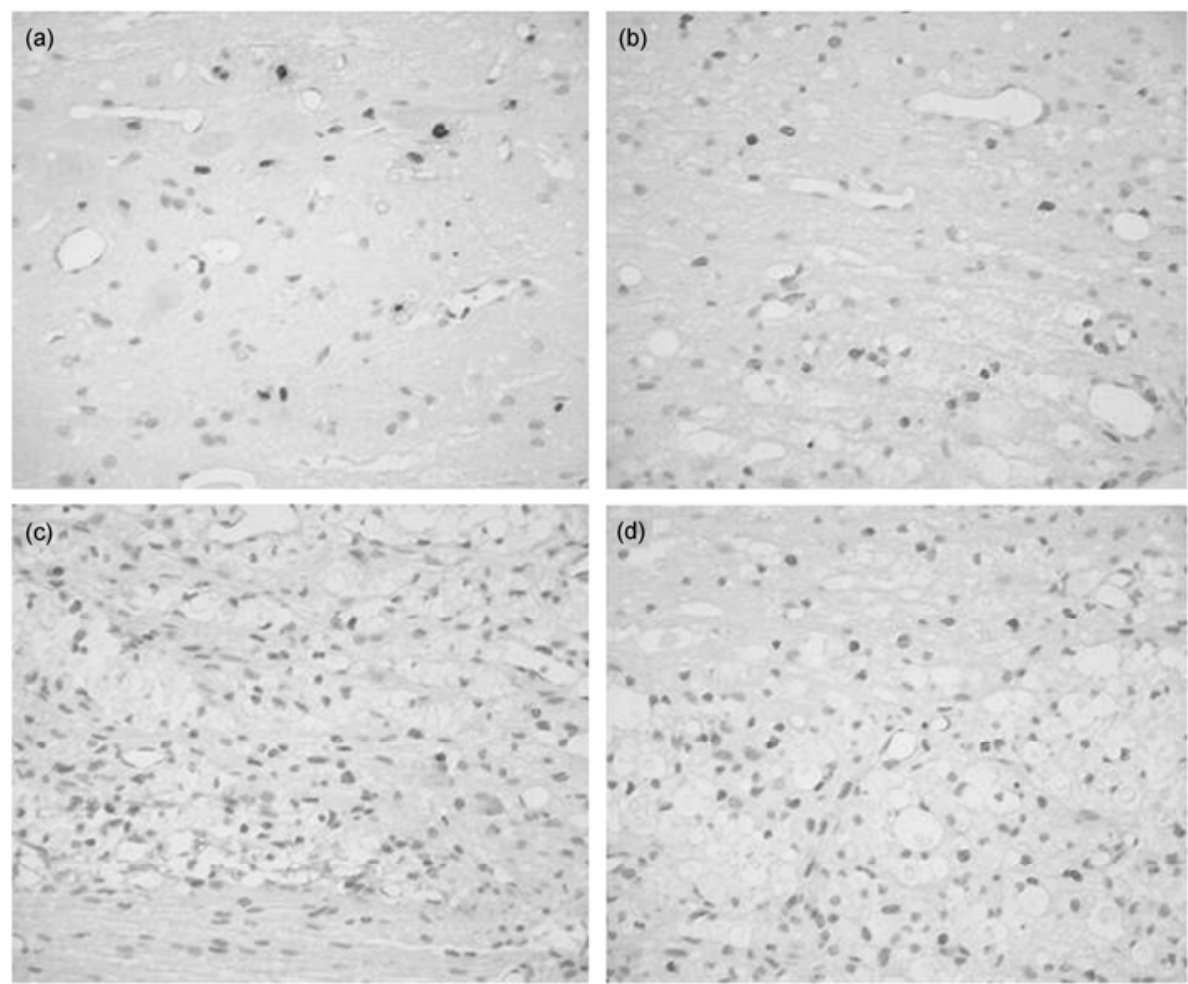

Figure 2 Representative images of bromodeoxyuridine (BrdU) immunostaining in spinal cord tissue from sham-treated rats (a), control rats (b), rats receiving electroacupuncture preconditioning treatment (c), and rats receiving electroacupuncture treatment for 1 week after spinal cord transection (d).
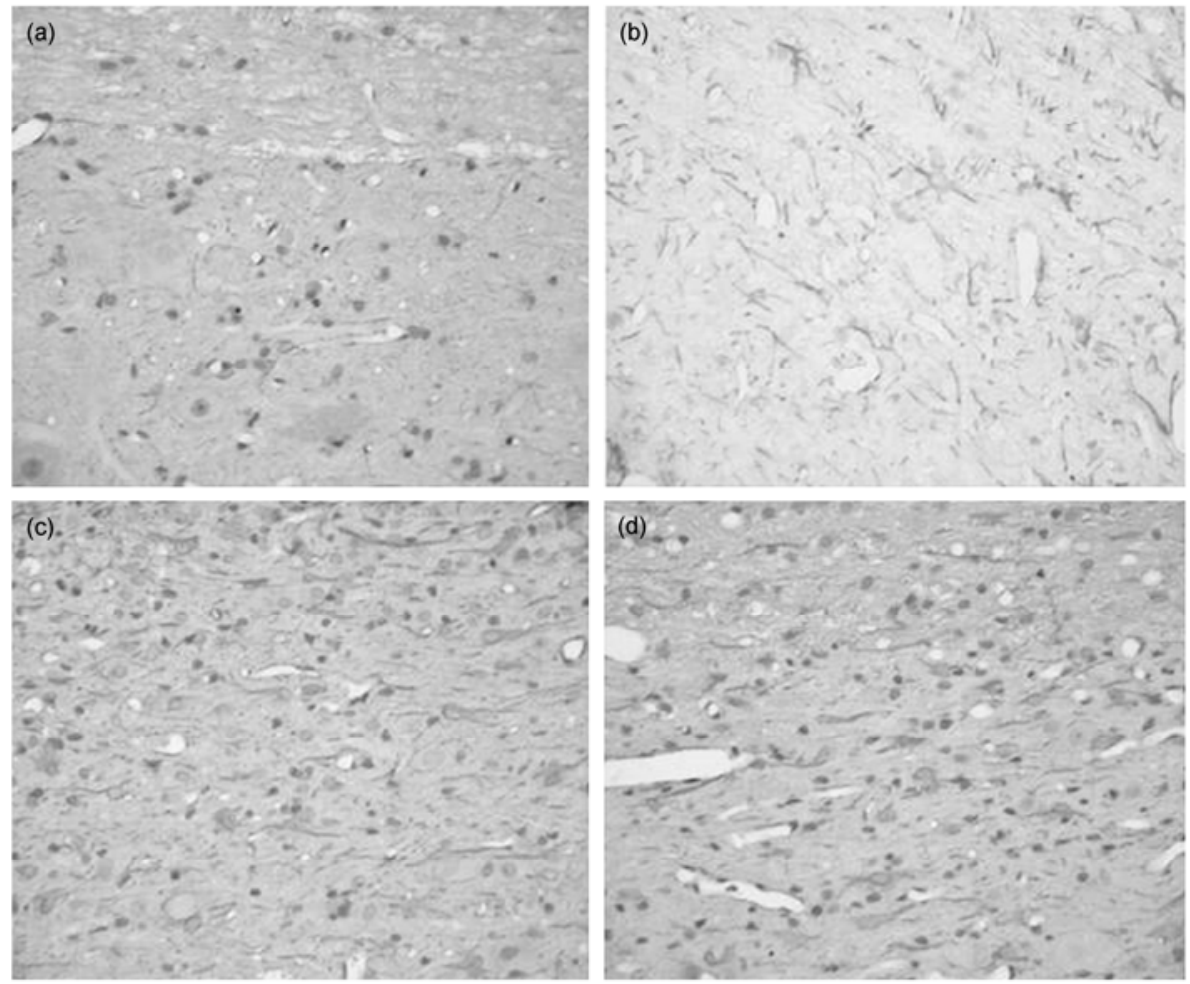

Figure 3 Representative images of glial fibrillary acidic protein (GFAP) immunostaining in spinal cord tissue from sham-treated rats (a), control rats (b), rats receiving electroacupuncture preconditioning treatment (c), and rats receiving electroacupuncture treatment for 1 week after spinal cord transection (d). 
Table 2 Neural stem cell marker immunopositivity among groups (cell number per square $\mathrm{mm})^{\mathrm{a}}$

\begin{tabular}{|c|c|c|c|c|c|}
\hline & Sham $(n=4 /$ time point $)$ & $\begin{array}{c}\text { Control } \\
(n=4 / \text { time point })\end{array}$ & $\begin{array}{l}\text { Electroacupuncture } \\
(n=4 / \text { time point })\end{array}$ & $\begin{array}{l}\text { Preconditioning } \\
(n=4 / \text { time point })\end{array}$ & $P$ value \\
\hline \multicolumn{6}{|l|}{ Day 3} \\
\hline Nestin & $4.7 \pm 1.9^{\mathrm{a}}$ & $38.4 \pm 5.4^{\mathrm{b}}$ & $86.3 \pm 2.3^{c}$ & $111.3 \pm 3.7^{\mathrm{d}}$ & $<0.001^{*}$ \\
\hline BrdU & $60.9 \pm 6.5^{\mathrm{a}}$ & $263.8 \pm 9.8^{\mathrm{b}}$ & $590.9 \pm 18.7^{\mathrm{c}}$ & $860.9 \pm 22.0^{\mathrm{d}}$ & $<0.001^{*}$ \\
\hline GFAP & $34.1 \pm 3.4^{\mathrm{a}}$ & $73.4 \pm 4.7^{\mathrm{b}}$ & $183.4 \pm 4.1^{\mathrm{c}}$ & $274.7 \pm 19.6^{\mathrm{d}}$ & $<0.001^{*}$ \\
\hline \multicolumn{6}{|l|}{ Day 7} \\
\hline Nestin & $3.4 \pm 1.2^{\mathrm{a}}$ & $67.8 \pm 5.3^{\mathrm{b}}$ & $123.4 \pm 5.1^{\mathrm{c}}$ & $170.0 \pm 5.9^{\mathrm{d}}$ & $<0.001^{*}$ \\
\hline $\operatorname{BrdU}$ & $60.9 \pm 8.3^{\mathrm{a}}$ & $416.6 \pm 20.2^{\mathrm{b}}$ & $890.9 \pm 39.5^{\mathrm{c}}$ & $1508.1 \pm 26.0^{\mathrm{d}}$ & $<0.001^{*}$ \\
\hline GFAP & $30.6 \pm 5.3^{\mathrm{a}}$ & $129.7 \pm 11.0^{\mathrm{b}}$ & $276.3 \pm 22.9^{c}$ & $442.8 \pm 8.3^{\mathrm{d}}$ & $<0.001^{*}$ \\
\hline \multicolumn{6}{|l|}{ Day 14} \\
\hline Nestin & $5.0 \pm 1.0^{\mathrm{a}}$ & $30.9 \pm 3.7^{\mathrm{b}}$ & $74.7 \pm 2.1^{\mathrm{c}}$ & $104.4 \pm 3.9^{\mathrm{d}}$ & $<0.001^{*}$ \\
\hline BrdU & $55.6 \pm 8.6^{\mathrm{a}}$ & $99.1 \pm 4.7^{\mathrm{b}}$ & $439.1 \pm 12.2^{\mathrm{c}}$ & $834.7 \pm 19.2^{\mathrm{d}}$ & $<0.001^{*}$ \\
\hline GFAP & $32.2 \pm 4.5^{\mathrm{a}}$ & $48.8 \pm 6.5^{\mathrm{b}}$ & $172.5 \pm 8.4^{\mathrm{c}}$ & $231.6 \pm 13.3^{\mathrm{d}}$ & $<0.001^{*}$ \\
\hline
\end{tabular}

a) Data are presented as mean \pm standard deviation (SD) number of cells, and differences were tested by 1-way analysis of variance (ANOVA). Tukey or Dunnett test was used for post-hoc analysis. *, Significantly different among the 4 groups. Different letters $(\mathrm{a}, \mathrm{b}, \mathrm{c}, \mathrm{d})$ indicate significant $(P<0.05)$ differences between groups. BrdU, bromodeoxyuridine; GFAP, glial fibrillary acidic protein.

Table 3 mRNA expression for neural stem cell markers among groups ${ }^{\text {a) }}$

\begin{tabular}{|c|c|c|c|c|c|}
\hline & Sham $(n=4 /$ time point $)$ & Control ( $n=4 /$ time point $)$ & $\begin{array}{r}\text { Electroacupuncture } \\
(n=4 / \text { time point })\end{array}$ & $\begin{array}{l}\text { Preconditioning } \\
(n=4 / \text { time point })\end{array}$ & $P$ value \\
\hline \multicolumn{6}{|l|}{ Day 3} \\
\hline GAPDH & $16.4 \pm 0.7$ & $17.1 \pm 0.5$ & $17.0 \pm 0.4$ & $17.1 \pm 0.5$ & 0.249 \\
\hline GFAP & $19.8 \pm 0.9^{\mathrm{a}}$ & $17.3 \pm 1.0^{\mathrm{b}}$ & $14.5 \pm 0.5^{\mathrm{c}}$ & $13.9 \pm 0.4^{\mathrm{c}}$ & $<0.001^{*}$ \\
\hline Nestin & $27.4 \pm 0.6^{\mathrm{a}}$ & $23.7 \pm 0.7^{b}$ & $22.2 \pm 0.7^{\mathrm{c}}$ & $21.1 \pm 0.3^{\mathrm{c}}$ & $<0.001^{*}$ \\
\hline \multicolumn{6}{|l|}{ Day 7} \\
\hline GAPDH & $17.0 \pm 0.4$ & $17.7 \pm 0.2$ & $17.7 \pm 0.7$ & $17.6 \pm 0.3$ & 0.108 \\
\hline GFAP & $20.0 \pm 0.7^{\mathrm{a}}$ & $16.9 \pm 0.6^{b}$ & $14.7 \pm 0.5^{\mathrm{c}}$ & $12.2 \pm 0.6^{\mathrm{d}}$ & $<0.001^{*}$ \\
\hline Nestin & $27.0 \pm 0.9^{\mathrm{a}}$ & $24.8 \pm 0.5^{\mathrm{b}}$ & $22.0 \pm 0.4^{\mathrm{c}}$ & $19.8 \pm 0.4^{\mathrm{d}}$ & $<0.001^{*}$ \\
\hline \multicolumn{6}{|l|}{ Day 14} \\
\hline GAPDH & $17.3 \pm 0.7$ & $17.9 \pm 0.5$ & $17.5 \pm 0.5$ & $17.5 \pm 0.6$ & 0.567 \\
\hline GFAP & $19.3 \pm 0.6^{\mathrm{a}}$ & $17.4 \pm 0.4^{\mathrm{b}}$ & $14.7 \pm 0.6^{\mathrm{c}}$ & $13.8 \pm 0.6^{\mathrm{c}}$ & $<0.001^{*}$ \\
\hline Nestin & $27.5 \pm 0.8^{\mathrm{a}}$ & $24.6 \pm 0.5^{\mathrm{b}}$ & $22.0 \pm 0.5^{\mathrm{c}}$ & $20.8 \pm 0.6^{\mathrm{c}}$ & $<0.001^{*}$ \\
\hline
\end{tabular}

a) Data are presented as mean \pm standard deviation (SD) of cycle numbers (smaller numbers indicate higher amounts) and were tested by 1-way analysis of variance (ANOVA). Tukey or Dunnett test was used for post-hoc analysis. *, Significantly different among the 4 groups. Different letters (a, b, c, d) indicate significant $(P<0.05)$ differences between groups. GAPDH, glyceraldehyde 3-phosphate dehydrogenase; GFAP, glial fibrillary acidic protein.

Table 4 Numbers of rats with detectable L2-T8 conduction

\begin{tabular}{ccccc}
\hline & Sham $(n=8 /$ time point $)$ & Control $(n=8 /$ time point $)$ & Electroacupuncture $(n=8 /$ time point $)$ & Preconditioning $(n=8 /$ time point $)$ \\
\hline Day 3 & 8 & 0 & 1 & 1 \\
Day 7 & 8 & 1 & 3 & 4 \\
Day 14 & 8 & 3 & 4 & 7 \\
\hline
\end{tabular}

to neural stem cells after spinal cord injury in rats [30]. Therefore, we believe that the combination of these 3 markers is indicative of neural stem cell activation.

Results of motor function assessments were mirrored by neural conduction experiments, showing a lack of spinal cord EPs after transection followed by partial recovery within 7 to $14 \mathrm{~d}$. This improvement was enhanced by Jiaji electroacupuncture, and particularly by preconditioning. We did not perform a quantitative comparison of wave amplitude height, but visual assessment showed no marked differences between groups. EP conduction in the spinal cord was shorter and spinal cord conduction velocity was elevated in the electroacupuncture groups (more so in the preconditioning group) compared with the control group at 7 and $14 \mathrm{~d}$ after transection.

Studies have shown that acupuncture preconditioning can 
exert favorable protective effects on hypoxia and ischemia in the heart, brain, gastrointestinal tract, and spinal cord, and it has been suggested that preconditioning induces a protective effect via generation of a trigger factor [31]. Our present results showed a greater effect in the Jiaji electroacupuncture preconditioning group than in the postinjury electroacupuncture treatment group. Thus, preconditioning may also promote endogenous neural stem cell activation. Future studies will be required to confirm the present findings and to further elucidate the mechanisms underlying the effects of Jiaji electroacupuncture on endogenous neural stem cells.

1 Lie D C, Song H, Colamarino SA, et al. Neurogenesis in the adult brain: New strategies for central nervous system diseases. Annu Rev Pharmacol Toxicol 2004, 44: 399-421

2 Zhang H, Yin Z S. Progression on repairing experimental spinal cord injury by neural stem cells (in Chinese). Foreign Med Sci (Biomed Engineer Fascicle), 2005, 28: 160-163

3 Ingras S. Reaction of cells to the galvanic current in tissue cultures. Proc Socexpbiol Med, 1920, 17: 189-198

4 Qun L. Electrical stimulation promotes proliferation and differentiation of endogenous neural stem cells in normal and injured spinal cord (in Chinese). Acupunct Res, 2008, 33: 34-36, 40

5 Zhao M, Song B, Pu J, et al. Electrical signals control wound healing through phosphatidylinositol-3-OH kinase-gamma and PTEN. Nature, 2006, 442: 457-460

6 Cui X J, Li Y W, Chen D F, et al. Effect of Du Channel electrotherapy on neural stem cell following injuried spinal cord (in Chinese). Anat Res, 2002, 24: 180-183

7 Ding Y, Yan Q, Ruan J W, et al. Electro-acupuncture promotes survival, differentiation of the bone marrow mesenchymal stem cells as well as functional recovery in the spinal cord-transected rats. BMC Neurosci, 2009, 10: 35

8 He L N, Yuan Z, Chen W, et al. Advance in empirical and clinical research of electrical stimulation for spinal cord injury (in Chinese). Chin J Rehabilit Theory Pract, 2009, 15: 720-722

9 Wang Z Y, Sun Z R, Liu R S. Effects of Jiaji electroacupuncture on cortical somatosensory evoked potentials in rats with spinal cord injury (in Chinese). Chin J Rehabilit Theory Pract, 2009, 15: 938-941

10 Cheng D A. The Study of Chinese Acupuncture and Moxibustion. Beijing: People's Medical Publishing House, 1955

11 Gao W B. New Therapy for Nerve Diseases With Acupuncture and Moxibustion. Beijing: People's Medical Health Publishing House, 2002

12 Wang X J, Kong K M. Research evolution of electric stimulus and spinal regeneration (in Chinese). J Shantou Univ Med College, 2002, 15: 58-60

13 Li T Y. Efficacy of spinal cord injury treated by Jiaji-electroacupuncture (in Chinese). Shanghai J Acupunct Moxibustion, 2002, 21: 42

14 Wu Y G, Sun Z R, Li X Y, et al. Studies on the influence of acupuncture on the changes of SCBF in injured rat spinal cord (in Chi- nese). Chin J Tradit Med Sci Technol, 1995, 2: 14-16

15 Borgens R B, Blight A R, Murphy D J, et al. Transected dorsal column axons within the guinea pig spinal cord regenerate in the presence of an applied electric field. J Comp Neurol, 1986, 250: 168-180

16 Fehlings M G, Tator C H, Linden R D. The effect of direct-current field on recovery from experimental spinal cord injury. J Neurosurg, 1988, 68: 781-792

17 Dong Y Q. The therapeutic effect of pulsed electric field on experimental spinal cord injury (in Chinese). Chin J Surg, 1992, 30: 180-183, 191

18 Zhang Z Y, Cui Y H, Yan Z G. The effect of electric acupuncture on apoptosis in spinal cord injury (in Chinese). Chin J Clin Rehabilit, 2002, 6: 818-819

19 Zhang Z Y, Yu A S, Yan Z G. Effects of electroacupuncture on expressions of bcl-2 mRNA and protein in the spinal cord in rats with early spinal cord injury (in Chinese). Chin Acupunct Moxibustion, 2003, 23: 473-476

20 Borgens R B, Blight A R, McGinnis M E. Functional recovery after spinal cord hemisection in guinea pigs: The effects of applied electric fields. J Comp Neurol, 1990, 296: 634-653

21 Coumans J V, Lin T T, Dai H N, et al. Axonal regeneration and functional recovery after complete spinal cord transection in rats by delayed treatment with transplants and neurotrophins. J Neurosci, 2001, 21: 9334-9344

22 Potas J R, Zheng Y, Moussa C, et al. Augmented locomotor recovery after spinal cord injury in the athymic nude rat. J Neurotrauma, 2006, 23: 660-673

23 Lin W Z. Experimental Acupuncture Science. Shanghai: Shanghai Science and Technology Publishing House, 1997

24 Zhang L, Xiong D L, Chen K H, et al. Effects of electro-acupuncture combined with bone marrow stromal cell transplantation on recovery of neurological function in rats with spinal cord injury (in Chinese). J Clin Rehabilit Tissue Eng Res, 2009, 13: 5217-5220

25 Basso D M, Beattie M S, Bresnahan J C. Graded histological and locomotor outcomes after spinal cord contusion using the NYU weightdrop device versus transection. Exp Neurol, 1996, 139: 244-256

26 Pfaffl M W, Horgan G W, Dempfle L. Relative expression software tool (REST) for group-wise comparison and statistical analysis of relative expression results in real-time PCR. Nucleic Acids Res, 2002, 30: e36

27 Gritti A, Parati E A, Cova L, et al. Multipotential stem cells from the adult mouse brain proliferate and self-renew in response to basic fibroblast growth factor. J Neurosci, 1996, 16: 1091-1100

28 Ao Q, Wang A J, Chen G Q, et al. Combined transplantation of neural stem cells and olfactory ensheathing cells for the repair of spinal cord injuries. Med Hypotheses, 2007, 69: 1234-1237

29 Iriki A, Sakura O. The neuroscience of primate intellectual evolution: Natural selection and passive and intentional niche construction. Philos Trans R Soc Lond B Biol Sci, 2008, 363: 2229-2241

30 Lang B, Liu H L, Liu R, et al. Astrocytes in injured adult rat spinal cord may acquire the potential of neural stem cells. Neuroscience, 2004, 128: 775-783

31 Tatlisumak T, Takano K, Carano R A, et al. Delayed treatment with an adenosine kinase inhibitor, GP683, attenuates infarct size in rats with temporary middle cerebral artery occlusion. Stroke, 1998, 29: $1952-1958$

Open Access This article is distributed under the terms of the Creative Commons Attribution License which permits any use, distribution, and reproduction in any medium, provided the original author(s) and source are credited. 